\title{
MODELING OF A SORAR LITHIUM BRMMIDE-WATER ABSORPTION AIR CONDITIONER IN BEIRUT
}

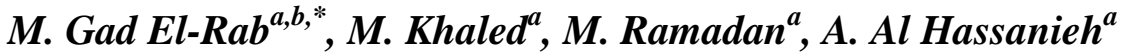 \\ ${ }^{a}$ Mechanical Engineering Department, School of Engineering, Lebanese International \\ University LIU, Beirut, Lebanon \\ ${ }^{b}$ Mechanical Power Engineering Department, Faculty of Engineering, Minoufyia University, \\ Shebin El-kom, Egypt \\ Corresponding Author : mostafa.gadelrab@liu.edu.lb
}

\begin{abstract}
A Single-stage lithium bromide absorption chiller driven by solar water heater is investigated in this paper. In the recent study, system description, modeling and simulation are introduced for $\mathrm{LiBr}-\mathrm{H} 2 \mathrm{O}$ absorption air conditioning system. This system has been proposed for an apartment has about $30 \mathrm{~kW}$ cooling load. It is found that the obtained COP can reach up to 0.9 at absorber temperature $30^{\circ} \mathrm{C}$ and generator temperature around $70^{\circ} \mathrm{C}$ which can be obtained from an evacuated tube solar collector.

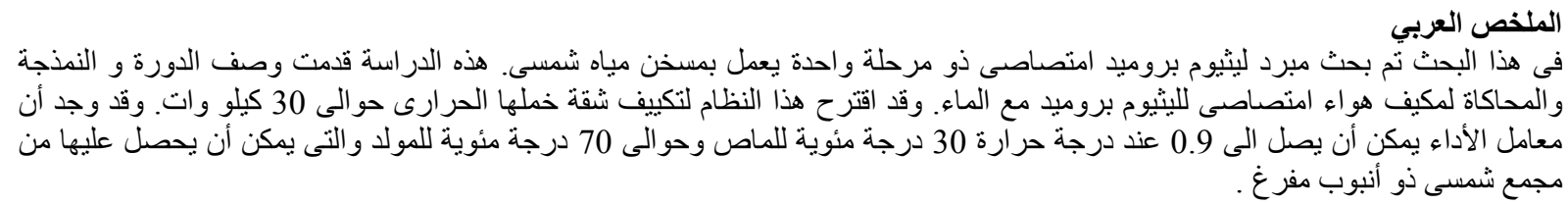

Keywords: Solar heat source, absorption chillers, low-grade temperature, refrigeration and air conditioning

\section{INTRODUCTION}

The main drawbacks for absorption cooling systems are the high initial cost and that of the required heat source for generation, so the integration of solar collectors as a heat source for such units makes these systems economical and reliable for commercial purposes for domestic use. Peak cooling demand in summer is associated with high availability of solar radiation, which offers an excellent opportunity to utilize solar energy in a heatdriven cooling system [1]. Development of this technology has been carried over the last 30 years with most work done in the last decade. It is now mature enough to show a strong potential for significant primary energy savings. In particular, for southern European, Mediterranean areas and Arabia, solar assisted cooling systems can bring energy savings in the range of 40 to $50 \%$ [2]. For low power cooling systems a strong focus exists for research on applications including photovoltaic-operated refrigeration cycles and solar mechanical refrigeration [3]. The phenomenon of absorption is caused when a mixture of two fluids (gas or liquid) is present in a solution. For cooling purpose, this phenomenon must also be easily reversible. Absorption systems are similar to vapor-compression air conditioning systems but differ in the pressurization stage [4].
There are two main types of machines that use the Absorption cycle; the single effect machines and the double and triple effect machines. The single-effect machine operates efficiently with a heat supply temperature of $80^{\circ} \mathrm{C}$ to $100^{\circ} \mathrm{C}$. Double and tripleeffect machines require higher supply temperatures, if the solar supplied temperature drops below $100^{\circ} \mathrm{C}$, the performance will drop sharply, below that of a single-effect system. Most large-scale applications with $300 \mathrm{KW}$ capacity and higher, use $\mathrm{LiBr} / \mathrm{H}_{2} \mathrm{O}$ as working pair, and produce chilled water at about $6^{\circ} \mathrm{C}$ to $7^{\circ} \mathrm{C}$. $\mathrm{LiBr}$ systems must be water cooled, usually requiring a cooling tower.

Due to the large vapor volume of the water refrigerant, the $\mathrm{LiBr} / \mathrm{H}_{2} \mathrm{O}$ chillers usually have large physical dimensions. In hot and sunny climates, the required solar collector area is approximately 3 to 4 $\mathrm{m}^{2}$ per $\mathrm{kW}$ cooling. Higher heat supply temperature for multi effect chillers require higher cost evacuated tube or concentrating collectors, and may need high temperature storage (i.e., thermochemical). In $\mathrm{LiBr} / \mathrm{H}_{2} \mathrm{O}$ systems, the refrigerant freezes at $0^{\circ} \mathrm{C}$. Thus, care must be exercised while the machine is idle, especially during winter. Another problem is crystallization of the $\mathrm{LiBr}$ solution at high concentrations, which may result from high generator temperatures or from inadequate temperature control at other parts of the machine. Thus, the heat supply temperature from the solar collectors or heat storage must be adequately controlled. 
The cooling water temperature, particularly to the absorber, must also be monitored. The chiller capacity may be controlled by increasing the heat supply temperature or decreasing the cooling water temperature, since both increase the capacity as well as the COP. A fuel-fi red boiler usually covers the need for a backup system to heat the desorber of the heat-driven chiller [5].

A feasible design solution for a single effect absorption cycle is to incorporate an auxiliary desorber, which is powered by the backup while the original desorber is powered by solar heat. The weak solution goes first to the solar-powered desorber where it is concentrated as much as possible with the available solar heat and then proceeds to the auxiliary desorber where it is concentrated further using heat from the backup source. The vapor from both desorbers is then supplied to the condenser.

A lithium bromide salt solution in the chiller boils and produces water vapor as a refrigerant that subsequently is condensed; its evaporation at low pressure produces the cooling effect in the chiller. This is transferred to the interior of the Audubon Nature Center by chilled water that is pumped through the evaporator in the chiller and then through fan coil units in the building. The internal air in the building is blown across the coils that contain the chilled water, providing the interior cooling.

The third main component in the system is a Marley cooling tower. For the chiller, the nominal generator temperature is $88{ }^{\circ} \mathrm{C}$, the cooling water inlet temperature is $30{ }^{\circ} \mathrm{C}$, and the chilled water outlet temperature is $9{ }^{\circ} \mathrm{C}$. A small amount of electricity is required to run the pumps that move the chilled water and hot water, and run the fans and this too is completely solar-powered by a solarphotovoltaic system (more than 200 crystalline-PV panels) and battery bank that also powers the building's lights and electrical equipment.

Flat plate collectors generally are not suitable in these applications, due to their low efficiencies. Parabolic trough collectors have high enough efficiencies, but their tracking mechanism is an added expense, and there are maintenance and service requirements for both the tracking device and keeping the reflecting surfaces clean. A nice feature of the vacuum tubes is that they can be removed and replaced without affecting the operation of the array $[6,7]$. The main objective of this paper is studying the effect of operating conditions on the performance of the solar absorption lithium-Bromide absorption air conditioner (AC) as well as the using of domestic water heater with the recent absorption AC.

\section{SYSTEM DESCRIPTION}

a. Solar Collector and Storage Tank Unit

Figure 1 shows the schematic of the LiBr-water chiller system integrated with a hot water storage tank heated from the evacuated tube solar collector.

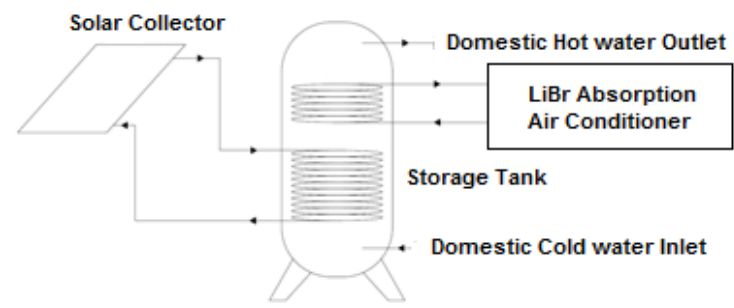

Figure 1: Layout of hybrid solar domestic water heating and the absorption air conditioner

\section{b. Local Solar Radiation in Lebanon}

Figure 2 shows the yearly variation of the cooling load of a typical apartment and solar radiation in Beirut City, Lebanon [1].

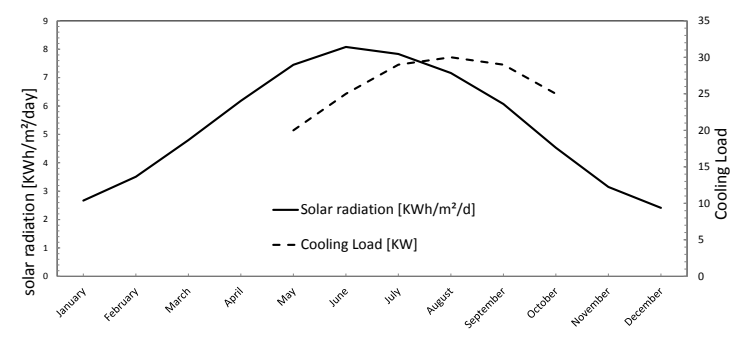

Figure 2: Variation of the cooling load and solar radiation in Beirut

Solar radiation has major effects on heat gain of a surface. Different factors contribute to maximize or minimize these effects; the most effective factors are the location of the sun in the sky, clearness of the atmosphere, nature of the surface and its orientation. Determining the position of the sun with respect to the earth during the day and throughout the year is very useful in predicting the amount of solar radiation on a specific location on the earth. In designing a solar collector and in making energy studies it is very important to determine the total solar energy striking a surface and the amount of thermal radiation absorbed [8].

\section{c. Lithium Bromide Absorption System}

The water-cooled single effect $\mathrm{LiBr}-\mathrm{H}_{2} \mathrm{O}$ absorption AC system can be shown as in figure 3 . Absorption chiller powered by solar energy can be utilized since the temperature requirements for using as a heat source is low temperature range [9]. 


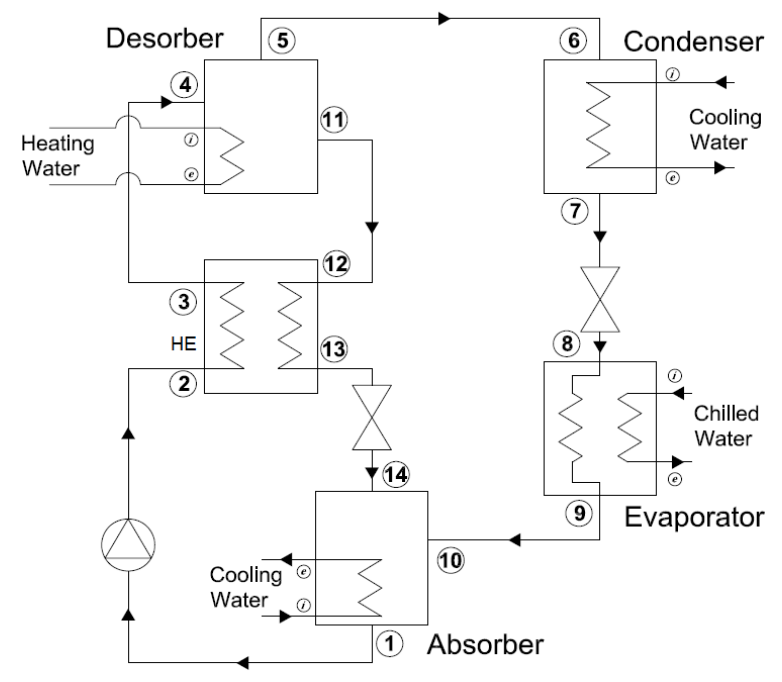

Figure 3: Single-Effect $\mathrm{LiBr}-\mathrm{H}_{2} \mathrm{O}$ Absorption Refrigeration Cycle

\section{SYSTEM MODEL}

The composition of a solution is generally expressed by the mass fraction of its components in a solution containing lithium bromide $(\mathrm{LiBr})$ and water; $\mathrm{X}$ is used to indicate the mass fraction of lithium bromide $[10,11]$ :

$X=\frac{m_{L i B r}}{m_{L i B r}+m_{w}}$

$m_{L i B r}=$ mass of lithium bromide in solution, $(\mathrm{kg})$

$m_{w}=$ mass of water in solution, $(\mathrm{kg})$

The total pressure of a solution is equal to the sum of the vapor pressures of the solute and of the solvent. In the case of a lithium bromide-water solution, the vapor pressure of pure $\mathrm{LiBr}$ can be ignored because its value is much smaller than that of water.

When water is mixed with anhydrous lithium bromide at the same temperature to form a solution adiabatically, there is a significant increase in the temperature of the solution. If the mixing process is to be an isothermal process, if the temperature of the process is to be kept constant, then heat must be removed from the solution. Such a heat transfer per unit mass of solution is called the integral heat of the solution $\Delta \mathrm{h}_{\mathrm{i}}$, or heat of absorption, in $\mathrm{kJ} / \mathrm{kg}$ or $(\mathrm{Btu} / \mathrm{lb})$. Based on the common rule of thermodynamics, $\Delta \mathrm{h}_{\mathrm{i}}$ is negative. $\mathrm{LiBr}$ solution is formed by an isothermal process, and its specific enthalpy $\mathrm{h}$, in $\mathrm{kJ} / \mathrm{kg}$ or (Btu/lb), may be expressed as

$h=(1-X) h_{w}+X h_{l}+\Delta h_{i}$

Where $h_{w}, h_{l}$ are the specific enthalpy of water and $\mathrm{LiBr}$, respectively, $\mathrm{kJ} / \mathrm{kg}$ or $(\mathrm{Btu} / \mathrm{lb})$.
Both mass and energy balance for each component of the system can be introduced as the following:

\section{Absorber}

The Absorber is a combination of an open and closed type heat exchanger operating at the lower pressure originally containing the weak solution. Water and concentrated $\mathrm{LiBr}$ solution enters at inlets 14 and 10, as LiBr solution is pumped out from outlet 1 , cooling water enters and leaves through inlet and outlet rejecting heat $\mathrm{Q} a$, considering the efficiency to be $100 \%$ the heat balance equation is:

$m_{1} h_{1}+Q_{a}=m_{10} h_{10}+m_{14} h_{14}$

Mass balance equation is:

$m_{1}=m_{10}+m_{14}$

Where $\mathrm{m}$ is mass flow rate in $\mathrm{Kg} / \mathrm{s}, \mathrm{Q}$ is heat in $\mathrm{KW}$ and $h$ is enthalpy in $\mathrm{Kj} / \mathrm{Kg}$.

\section{Heat Exchanger}

The low temperature weak solution (w.s) pumped to the generator entering the closed type heat exchanger at inlet 2 and leaving from outlet 3 is preheated from the high temperature strong solution (s.s) leaving the generator entering at inlet 12 and leaving from outlet 13 , heat balance equation is:

$m_{w . s}\left(h_{3}-h_{2}\right)=m_{s . s}\left(h_{12}-h_{13}\right)$

$\varepsilon=\frac{\mathrm{T}_{3}-\mathrm{T}_{2}}{\mathrm{~T}_{12}-\mathrm{T}_{2}}$

Mass balance equation is:

$m_{2}+m_{12}=m_{3}+m_{13}$

Where $\varepsilon$ is exchanger's effectiveness and $\mathrm{T}$ are temperatures in ${ }^{\circ} \mathrm{C}$ or $\mathrm{K}$, and $\mathrm{m}$ is mass flow rate in $\mathrm{Kg} / \mathrm{s}$.

\section{Generator (Desorber)}

The generator or the desorber is a combination of an open and closed type heat exchanger operating at thehigher pressure. Heat is added from the solar source $\mathrm{Qg}$ to heat the solution entering at inlet 4 causing the evaporation and separation of water vapor leaving at outlet 5 where the strong solution leaves the container from outlet 11. Considering the efficiency to be $100 \%$ the heat balance equation is:

$m_{4} h_{4}+Q_{g}=m_{5} h_{5}+m_{11} h_{11}$ 
Mass balance equation is:

$m_{4}=m_{5}+m_{11}$

Where $\mathrm{m}$ is mass flow rate in $\mathrm{Kg} / \mathrm{s}, \mathrm{Q}$ is heat in $\mathrm{KW}$ and $\mathrm{h}$ is enthalpy in $\mathrm{Kj} / \mathrm{Kg}$.

\section{Condenser}

The Condenser is a closed type heat exchanger operating at the higher pressure. Water vapor enters at Intel 6 then condenses and leaves from outlet 7 then expanded to the evaporator. Heat $\mathrm{Q}_{\mathrm{C}}$ is rejected by cooling water. Considering the efficiency to be $100 \%$ the heat balance equation is:

$$
m_{6} h_{6}=m_{7} h_{7}+Q_{c}
$$

Mass balance equation is:

$$
m_{6}=m_{7}
$$

Where $\mathrm{m}$ is mass flow rate in $\mathrm{Kg} / \mathrm{s}, \mathrm{Q}$ is heat in $\mathrm{KW}$ and $h$ is enthalpy in $\mathrm{Kj} / \mathrm{Kg}$.

\section{Evaporator}

The evaporator is closed type heat exchanger operating at the lower pressure. Water enters at inlet 8 and leaves from outlet 9. The absorbed heat Qe will cause the cooling effect on the chilled water. Considering the efficiency to be $100 \%$ the heat balance equation is:

$m_{8} h_{8}+Q_{e}=m_{9} h_{9}$

Mass balance equation is:

$$
m_{8}=m_{9}
$$

Where $\mathrm{m}$ is mass flow rate in $\mathrm{Kg} / \mathrm{s}, \mathrm{Q}$ is heat in $\mathrm{KW}$ and $\mathrm{h}$ is enthalpy in $\mathrm{Kj} / \mathrm{Kg}$.

\section{SIMULATION AND RESULTS}

A steady state condition is assumed to simulate the proposed system, a 300 Liters hot water storage tank and average daily consumption of 100 Liters hot water at $50^{\circ} \mathrm{C}$ have been determined. While $\mathrm{Qg}$ equals $35 \mathrm{KW}$, the required solar collector area is 37 $\mathrm{m}^{2}[12,13]$. During winter the excess of solar panels can be utilized for space heating. The heat gain by solar collector can be determined according to the following equation:

$$
m_{w} c_{w}\left(T_{w, e^{-}} T_{w, i}\right)=A_{c} G \eta_{c}
$$

Where $\mathrm{m}_{\mathrm{w}}$ is the water mass flow rate $(\mathrm{kg} / \mathrm{s}), \mathrm{c}_{\mathrm{w}}$ water heat capacity (J/kg.k) and $T_{w, e}$ and $T_{w, i}$ are water temperatures from and into the solar collector respectively. $A_{c}$ is collector area $\left(\mathrm{m}^{2}\right), \mathrm{G}$ solar intensity $\left(\mathrm{W} / \mathrm{m}^{2}\right)$, and $\eta_{c}$ collector efficiency.

For doing the best simulation it is important to consider reasonable parameters relative to the environmental conditions and the typical operating condition are considered: Generator Temperature, $\mathrm{Tg}$ $72^{\circ} \mathrm{C}$, and $95^{\circ} \mathrm{C}$; Evaporator Temperature, Te $5^{\circ} \mathrm{C}$, $7^{\circ} \mathrm{C}, 12^{\circ} \mathrm{C}$, and $12^{\circ} \mathrm{C}$; Condenser Temperature, Tc $45^{\circ} \mathrm{C}$; Absorber Temperature, Ta $35^{\circ} \mathrm{C}$; Peak Cooling Load, Qe $30 \mathrm{KW}$; Exchangers effectiveness 0.8 . Figure 4 shows the presentation of the singlestage absorption cycle on the P-T-X diagram.

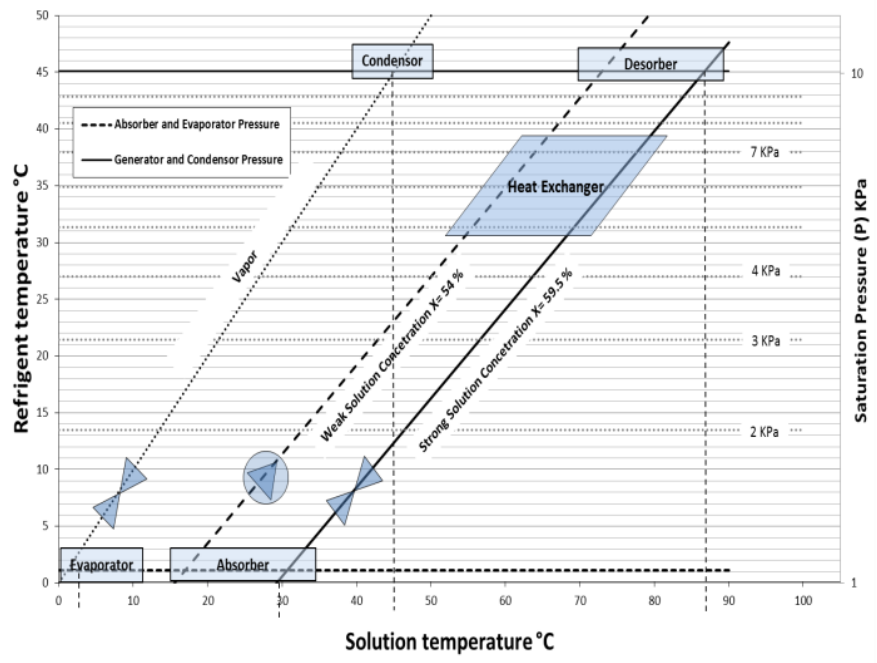

Figure 4: The presentation of P-T-X diagram for the single-stage absorption cycle

The recent modeling has been carried out according to the flow chart in figure 5 that indicates the procedure of calculation and simulation. 
Figure 6 shows the variation COP and the generator temperature $[\mathrm{Tg}]$ at condenser temperature

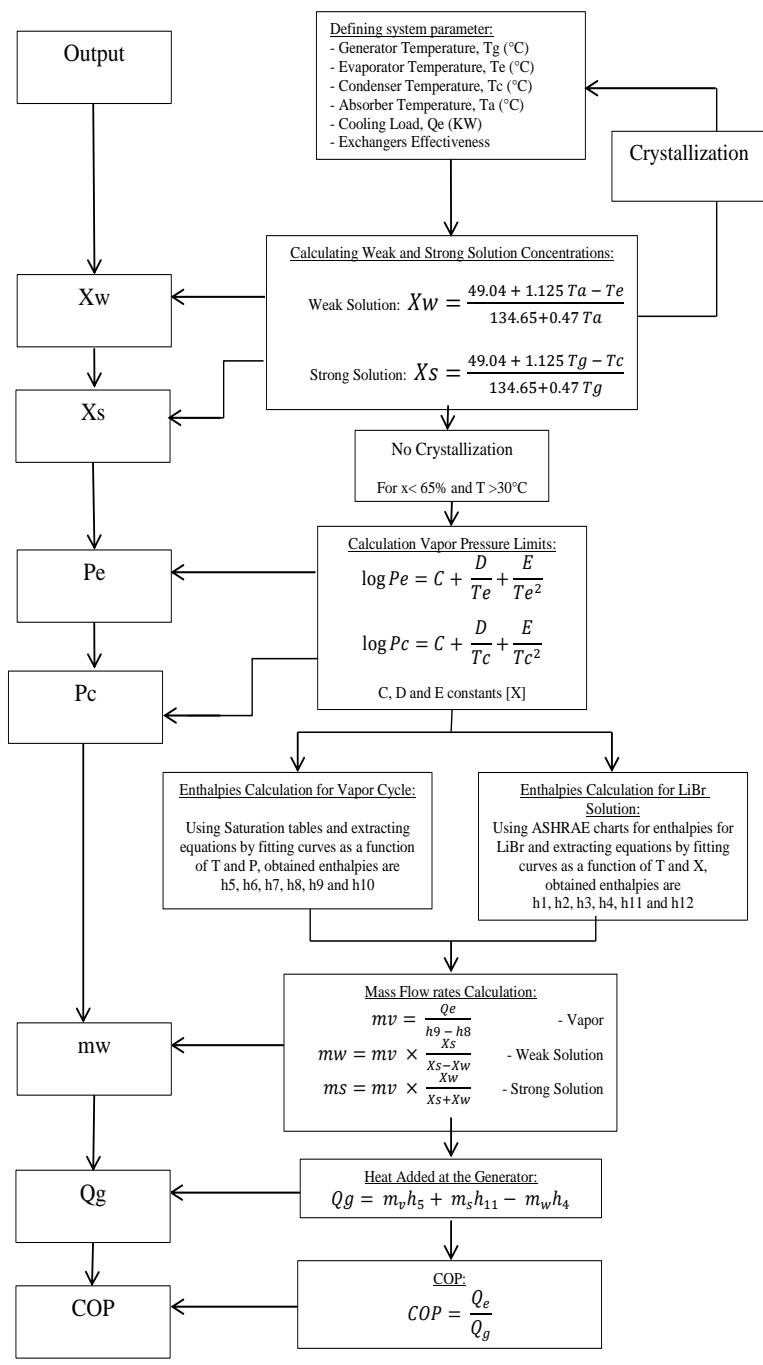

Figure 5: Flow chart of System Modeling

$\left[\mathrm{Tc}=45^{\circ} \mathrm{C}\right]$ and absorber temperature $\left[\mathrm{Ta}=35^{\circ} \mathrm{C}\right]$. The results show with increasing the generator temperature, $\mathrm{COP}$ will increase due to the increasing in released refrigerant in the generator.

In order to investigate the influence of the absorber temperature, figure 7 shows the variation $\mathrm{COP}$ and the absorber temperature [Ta] at evaporator temperature $\left[\mathrm{Te}=7{ }^{\circ} \mathrm{C}\right]$ which is widely used, condenser temperature $\left[\mathrm{Tc}=45^{\circ} \mathrm{C}\right]$ which is near the environmental conditions and generator temperature $\left[\mathrm{Tg}=91{ }^{\circ} \mathrm{C}\right]$ where the first highest $\mathrm{COP}$ is obtained at the lower absorber temperature due to the high performance of absorption process at lower temperature.

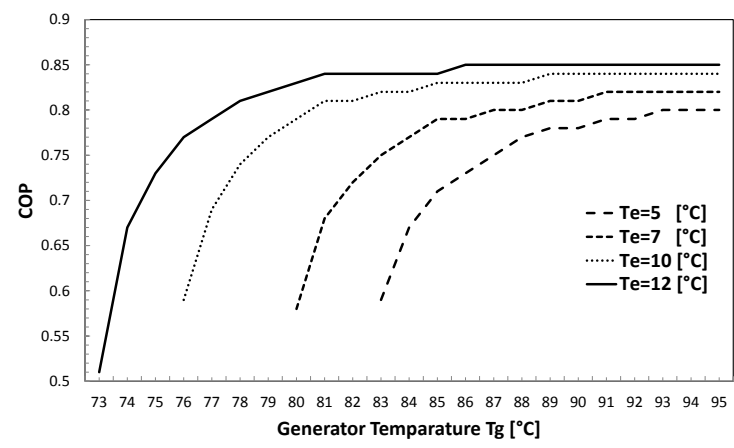

Figure 6: Variation of $\mathrm{COP}$ with $[\mathrm{Tg}]$ at $\left[\mathrm{Tc}=45^{\circ} \mathrm{C}\right]$ and $\left[\mathrm{Ta}=35^{\circ} \mathrm{C}\right]$

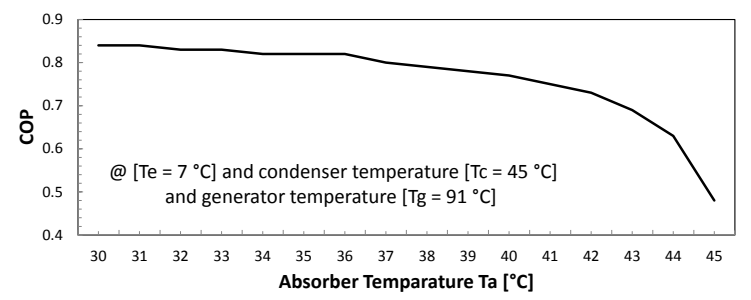

Figure 7: Variation of COP with $[\mathrm{Ta}]$ at $\left[\mathrm{Te}=7^{\circ} \mathrm{C}\right]$, $\left[\mathrm{Tc}=45^{\circ} \mathrm{C}\right]$ and $\left[\mathrm{Tg}=91^{\circ} \mathrm{C}\right]$

It is found that the best COP is at $[\mathrm{Ta}=$ $30^{\circ} \mathrm{C}$ ], but since $35^{\circ} \mathrm{C}$ is easily achieve in such local conditions it is good to consider it for a relatively good COP as shown in figure 8 .

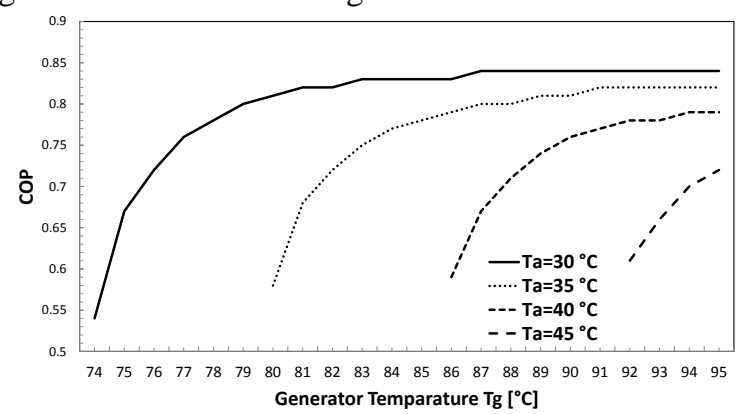

Figure 8: Variation of $\mathrm{COP}$ with $[\mathrm{Tg}]$ at $\left[\mathrm{Tc}=45^{\circ} \mathrm{C}\right]$ and $\left[\mathrm{Te}=7^{\circ} \mathrm{C}\right]$

The following series of variations of COP at different condition are made to show what parameters should be considered to improve the cycle's COP. Figure 9 shows the relationship between the $\mathrm{COP}$ and the generator temperature $[\mathrm{Tg}]$ for different condenser temperature at fixed absorber temperature $\left[\mathrm{Ta}=30^{\circ} \mathrm{C}\right]$ and evaporator temperature $\left[\mathrm{Te}=7^{\circ} \mathrm{C}\right]$. Figure 10 shows that it is insignificant to raise the generator temperature above an optimum value where the COP no longer improves.

Figures 6,8 , and 9 show that a high COP can be achieved at a relatively low generator temperature $\left[\mathrm{Tg}=70{ }^{\circ} \mathrm{C}\right]$. Figure 11 show that the COP also increase at low absorber temperature for higher evaporator temperature. 


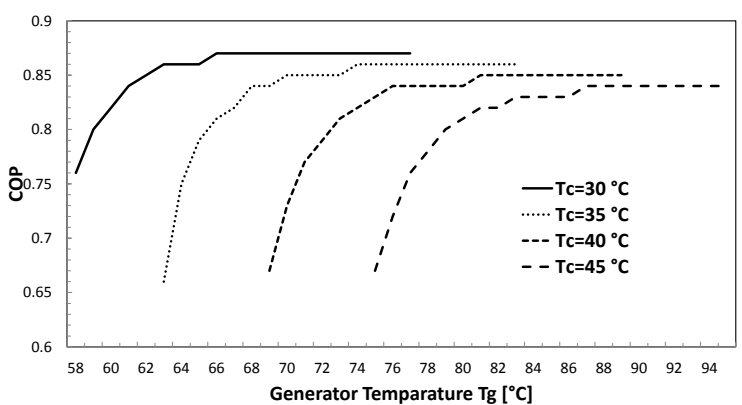

Figure 9: Variation of COP with $[\mathrm{Tg}]$ at $\left[\mathrm{Tc}=45^{\circ} \mathrm{C}\right]$ and $\left[\mathrm{Te}=7^{\circ} \mathrm{C}\right]$

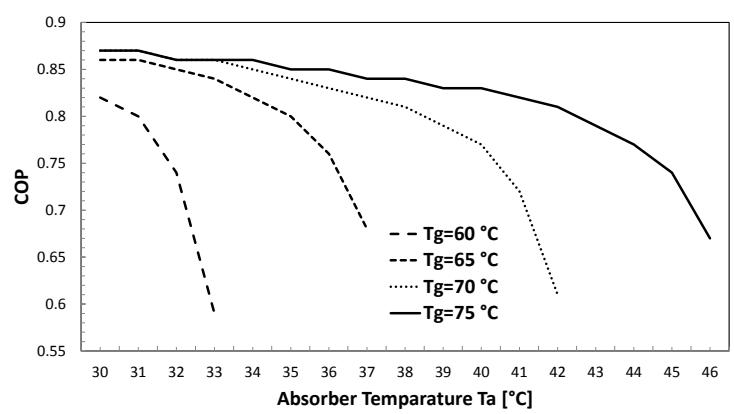

Figure 10: Variation of COP with $[\mathrm{Ta}]$ at $[\mathrm{Tc}=30$ $\left.{ }^{\circ} \mathrm{C}\right]$ and $\left[\mathrm{Te}=7{ }^{\circ} \mathrm{C}\right]$

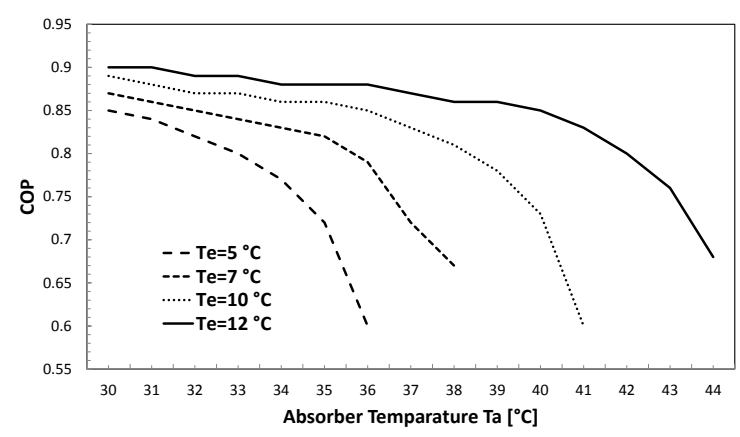

Figure 11: Variation of COP with $[\mathrm{Ta}]$ at $\left[\mathrm{Tg}=66^{\circ} \mathrm{C}\right]$ and $\left[\mathrm{Tc}=30^{\circ} \mathrm{C}\right]$

\section{CONCLUSION}

From the COP graphs versus the temperature of generator, absorber, condenser and evaporator, it can conclude that at $\mathrm{LiBr}$ absorption cycles can operate with a moderate hot water temperature driving the generator ranging between $70^{\circ} \mathrm{C}$ and $90^{\circ} \mathrm{C}$. The COP will reach an optimum value corresponding to a designated generator temperature where it longer rises as a function of this temperature. As for the condenser and absorber temperatures, it can conclude that the cycle operates at the range of $30^{\circ} \mathrm{C}$ to $45^{\circ} \mathrm{C}$ depending on the environmental condition, the lower the temperature of the absorber and the condenser is; the considerable COP could be obtained. $\mathrm{LiBr}$ absorption chillers are advantageous alternative clean cooling units when driven by solar heated water.
Investigating the double-effect $\mathrm{LiBr}$ absorption cycle and researching the ability to utilize waste heat or parabolic solar collector as a heat source for the generator could be an interesting topic for future work.

\section{REFERENCES}

[1] C.A. Blaras, H.M. Henning, E. Wiemken, G. Grossman, E. Podesser and C. A. Infante Ferreira. "Solar Cooling." ASHRAE Journal, 2006.

[2] A heat-pump system based on lithium bromide and water, Technical Report, 02 Jul 2014.

[3] Klein, S.A. and D.T. Reindl. "Solar refrigeration." ASHRAE Journal, 2005.

[4] 2002 ASHRAE Handbook-Refrigeration, Chapter 41.

[5] 2005 ASHRAE Handbook - Fundamentals, Chapter 22.

[6] Barry Jim On, P.E. and Min Zhong, P.E. "Solar Thermal Retrofit." ASHRAE Journal, 2012.

[7] Gregory White. "Solar-Thermal HVAC Technology Debuts in Los Angeles at New Audubon Urban Nature Center." SUN Utility Network, 2004.

[8] A. Al Hassanieh, M.A. Bou Dargham. "Hybrid thermal-photovoltaic tracking solar collector", FYP in partial fulfillment of the requirements of the MS degree of the Mechanical \& Electrical majors of the College of Engineering at the Hariri Canadian University, 2010.

[9] Faye C. McQuiston, Jerald D. Parker, and Jeffrey D. Spitler, Heating, Ventilating and Air Conditioning Analysis and Design, 2004.

[10] Alefeld, G., and Ziegler, F., Advanced Heat Pump and Air-Conditioning Cycles for the Working Pair H2O/LiBr: Domestic and Commercial Applications, ASHRAE Transactions, Part II B, pp. 2062-2071, 1985.

[11] S. A. A. Masheiti, Modelling of lithiumbromide $(\mathrm{LiBr})$ chiller and organic Rankin cycle (ORC) powered by low-temperature geothermal heat source, www.ncl.ac.uk/mech/ students/conference/.../Masheiti.pdf

[12] ASHRAE Handbook 1989, Fundamentals.

[13] Solar Simulator, on Viessmann products, TSOL, Technical Software, personal communications, http://www.valentinsoftware.com/en/products/solarthermal/14/tsol 